\title{
Roundup-induced biochemical and histopathological changes in the liver and kidney of rats: the ameliorative effects of Linum usitatissimum oil
}

\author{
Nesrine Djaber, Lynda Sabrina Ounaceur, Baya Nouha Moubine, Taha Khaldi, Mereim \\ Rouag, Salma Berrouague, Hichem Amara, Faiza Taibi, Mahieddine Boumendjel, \\ Amel Boumendjel and Mahfoud Messarah
}

Laboratory of Biochemistry and Environmental Toxicology, Faculty of Sciences, University of Badji Mokhtar, Annaba, Algeria

\begin{abstract}
The present study was undertaken to evaluate the protective effects of Linum usitatissimum oil (LuO) against sub-chronic Roundup (RDP)-induced toxicity and oxidative stress in rats. Rats were divided into four groups: control group (no treatment), RDP group (Roundup at $269.9 \mathrm{mg} / \mathrm{kg}$ b.w.), LuO group ( $0.5 \mathrm{~g} / \mathrm{kg}$ b.w. of LuO) and RDP+LuO group (RDP and LuO simultaneously). LuO decreased the ferric reducing antioxidant power (FRAP) $\left(\mathrm{IC}_{50}=10.36 \mu \mathrm{g} / \mathrm{ml}\right)$ and 2,2-diphenyl-1-picrylhydrazyl (DPPH) $\left(I C_{50}=22.85 \mathrm{mg} / \mathrm{ml}\right)$ in the tested tissues. The 30 day exposure of rats to RDP caused an increase in serum hepatic and renal markers: AST, ALT, ALP, LDH, yGT, bilirubin, urea, and creatinine. In addition, SOD, CAT and GST activities decreased by $43 \%, 61 \%$, and $61 \%$, respectively, while GPx activity, MDA and PCOs levels increased by $80 \%, 46 \%, 25 \%$, respectively. LuO treatment alleviated hepatotoxicity in RDP-treated rats, showing improved levels of oxidative stress biomarkers and plasma biochemical parameters. The histological examination of the liver and kidney confirmed the changes in Rounduptreated rats and demonstrated the protective role of LuO.
\end{abstract}

Key words: roundup, linseed oil, oxidative stress, hepatotoxicity, nephrotoxicity, rats

Received: 25 October, 2019; revised: 18 January, 2020; accepted: 13 February, 2020; available on-line: 18 March, 2020

Đe-mail: mahfoud.messarah@univ-annaba.dz; mmessarahdz@yahoo.fr

Acknowledgements of Financial Support: The present work was supported by DG-RSDT (General Directorate of Scientific Research and Technological Development-Algeria) via the Laboratory of Biochemistry and Environmental Toxicology, Faculty of Sciences, University of Badji Mokhtar-Annaba, Algeria.

Abbreviations: ALP, alkaline phosphatase; ALT, alanine transaminase; AST, aspartate transaminase; $\mathrm{LDH}$, lactate dehydrogenase; $\gamma$-GT, gamma glutamyl-transpeptidase; GSH, reduced glutathione; GPx, glutathione peroxidase; LPO, lipid peroxidation; MDA, malondialdehyde; TBA, thiobarbituric acid; TBARS, TBA reactive substances; NO, nitric oxide; AOPP, advanced oxidation protein product; PCO, protein carbonyl; RDP, Roundup; SOD, superoxide dismutase CAT, catalase; GST, glutathione-S-transferase; DNPH, carbonyl group with 2,4-dinitrophenylhydrazine.

\section{INTRODUCTION}

Organophosphate (OP) pesticides are among the most widely used synthetic chemicals to control a wide variety of pests and insects in agriculture, homes, gardens, veterinary practice and industry (Dar et al., 2019). Roundup (RDP) is an organophosphorus compound glyphosate ( $\mathrm{N}$-(phosphonomethyl)glycine), an active ingredient of many herbicides, such as Roundup ${ }^{\circledR}$ TURBO, and the most commonly used herbicide active ingredient in the world (El-Shenawy 2009). Glyphosate and its primary degradation product aminomethylphosphonic acid (AMPA) are detected in soils and sediment, ditches, drains, rainwater, rivers, and streams (Rebai et al., 2017). Roundup is marketed as a non-selective, broad spectrum and post-emergence herbicide due to its high water solubility. It kills plants by inhibiting the synthesis of aromatic amino acids needed for protein formation (Battaglin et al., 2014). Roundup is slightly toxic to fish, practically non-toxic to amphibians and aquatic invertebrate animals, and exhibits low oral and dermal acute toxicity to humans (Larsen et al., 2012). Over the last two decades, toxicological research has shown the induction of oxidative stress after exposure to pesticides as a possible mechanism of toxicity. According to several studies, the pesticides, including roundup, cause overproduction of reactive oxygen species (ROS) in intra- and extracellular spaces, resulting in the disruption of pro-oxidant equilibrium/cellular oxidative balance and leading to the oxidative stress state (El-Shenawy, 2009; Heritier et al., 2017). In humans, glyphosate is not fully absorbed after oral administration (approximately $20 \%$ of the dose administered is excreted in the urine after $48 \mathrm{~h}$ ), being mainly eliminated unchanged via the feces. The absorbed glyphosate is poorly metabolized, gets widely distributed in the body, does not undergo enterohepatic circulation and is rapidly eliminated without bioaccumulation ("Conclusion on the peer review of the pesticide risk assessment of the active substance glyphosate", 2015).

Indeed, in a study conducted in 2011 and 2012 in Denmark (Knudsen et al., 2017), urine spot samples of mothers $(n=13)$ and children $(n=14)$ revealed concentrations of glyphosate above the limit of detection (LOD, $2.5 \mu \mathrm{g} / \mathrm{L}$ ) in both urban and rural dwelling populations. It was found that when ROS formation exceeded the scavenging ability of antioxidant defenses, free radicals accumulated and increased oxidative damage to critical biomolecules such as enzymes, proteins, membrane lipids and DNA (Mohammadirad \& Abdollahi, 2011). Several studies indicate that glyphosate and GLP-based herbicide $(\mathrm{GBH})$ intoxication causes oxidative stress by generating free radicals and induces tissue lipid peroxidation. In response to oxidative damage, organisms have developed enzymatic antioxidant defense systems, which are represented mainly by superoxide dismutase (SOD), catalase (CAT), glutathione peroxidase (GPx), and glutathione reductase. These enzymes detoxify ROS and maintain a healthy redox state in a highly synchronized 
and cooperative manner (Tang et al., 2017; Yazdinezhad et al., 2017). Organophosphate pesticides was found to repress cytochrome $\mathrm{P} 450$ and two other enzymes (glutathione-S-transferase and G-6-P dehydrogenase) essential for xenobiotics detoxication in the body (Almeida $e t$ al., 2017). However, RDP toxicity towards serum acetylcholinesterase (AChE), lactate dehydrogenase (LDH), aspartate aminotransferase (AST), alanine aminotransferase (ALT), alkaline phosphatase (ALP), and acid phosphatase (AP) has been recently determined (Rebai et al., 2017; Tang et al., 2017). RDP poisoning can affect several organs, including the brain, heart, kidney, liver and reproductive system (Dai et al., 2016; Tizhe et al., 2014; Turkmen et al., 2019). Several epidemiological studies have shown the importance of increasing the antioxidant capacity of the body with exogenous antioxidants such as vitamins, carotenoids, trace elements and minerals (Djeffal et al., 2015; Barkat et al., 2015). Flaxseed or linseed (Linum usitatissimum) is an annual plant that belongs to the family Linaceae (Varghese et al., 2017). The research study of Hendawi and others (Hendawi et al., 2016) has shown that linseed oil obtained by the company El-capten contains high levels of unsaturated fatty acid: C18:1 (Oleic) (45.63\%), C18:3 ( $\gamma$-Linolenic) $(8.93 \%)$ and C18:2 (Linoleic) $(4.19 \%)$, as evaluated with gas liquid chromatography (GLC) of fatty acid methyl esters. In addition, it has been reported that linseed oil is among the most well-known edible oils in the world and is in demand as a nutritional supplement (Ye et al., 2019; Zhang et al., 2008). Being a source of $\alpha$-Linolenic acid, it is a precursor of eicosapentaenoic acid (EPA) and docosahexaenoic acid (DHA) (Rubilar et al., 2010) and plays an active role in the cell membrane integrity (Karaca \& Eraslan, 2013). Linseed is rich in $\mathrm{n}-3$ polyunsaturated fatty acids (PUFA), especially omega-3 fatty acid that has pharmacological and therapeutic effects, in particular, antidiabetic, antioxidant, anti-inflammatory, anti-cancer and immunomodulatory. Linseed is also used for the treatment of cardiovascular diseases, dermatological, neurological and hormonal disorders, and metabolic syndromes such as obesity (Hendawi et al., 2016; Jamilian et al., 2017; Varghese et al., 2017). L. usitatissimum is a source of healthy oil that has good anti-free radical properties and good oxidation stability, probably due to the changes in its fatty acid profile (Jamilian et al., 2017). To the best of our knowledge, no study has examined the protective effects of $\mathrm{LuO}$ on RDP-induced hepatotoxicity and nephrotoxicity. Therefore, the present study was conducted to assess some biochemical parameters, antioxidant status and histopathological alterations in the liver and kidney of RDP-exposed rats. It also tried to determine whether the treatment with $\mathrm{LuO}$ could alleviate RDP-induced toxicity.

\section{MATERIALS AND METHODS}

Chemicals. The herbicide used in this study was a commercial formulation (Roundup ${ }^{\circledR}$ TURBO) containing the active ingredient glyphosate $450 \mathrm{~g} / 1$. The chemical name for glyphosate is $\mathrm{N}$-phosphonomethyl glycine $\left(\mathrm{C}_{3} \mathrm{H}_{8} \mathrm{NO}_{5} \mathrm{P}\right)$ (Fig. 1), with a CAS registry number 1071-

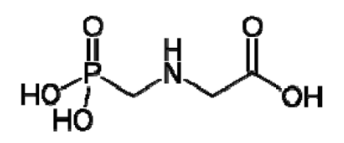

Figure 1. Chemical structure of glyphosate
83-6 and homologation number 0543 087. This product is made by MONSANTO firm and distributed by Agro Consulting International, Algeria.

Linseed Oil Resource. Linum usitatissimum oil was obtained from a local commercial market El-Captain (El-Obour City, Cairo, Egypt), a company for Extracting Natural Oils, Plants and Cosmetics. All the other reagents used in this study were purchased from Sigma Chemical Co. (St. Louis, MO).

Total phenolic acids content. Total phenolic acids content was measured using Folin-Ciocalteu reagent, following Wolfe and others (Wolfe et al., 2003). The total phenolic acids content of plant fragments was expressed in $\mathrm{mg}$ of gallic acid equivalents per gram of plant dry matter (mg GAE/g DM) through the calibration curve with gallic acid.

Total flavonoids content. Total flavonoid content was measured using a colorimetric assay according to the method of Pourmorad and others (Pourmorad et al., 2006). The concentrations of flavonoids, calculated based on a standard curve, were expressed in mg quercetin equivalent to $(\mathrm{QE}) / \mathrm{g}$ dry matter (DM).

Total tannins content. Total tannins content was estimated according to the protocol developed by Julkunen-Tiitto (Julkunen-Tiitto, 1985). The results are expressed in $\mathrm{mg}$ of catechin equivalent $(\mathrm{CE}) / \mathrm{g}$ DM.

DPPH radical scavenging activity. The antioxidant activity of $\mathrm{LuO}$ was measured in context of radical scavenging ability using the DPPH method of Blois (Blois, 1958). The antiradical activity was expressed as $\mathrm{IC}_{50}$ $(\mathrm{mg} / \mathrm{ml})$. The percent inhibition of DPPH free radical was calculated as follows:

$$
\text { I } \%=\left(\frac{A \text { blank }- \text { A sample }}{A \text { blank }}\right) \times 100
$$

Ferric reducing antioxidant power (FRAP) activity. The reducing power of a sample was determined using the method of Pan and others (Pan et al., 2008), where absorbance of a sample was measured at $700 \mathrm{~nm}$. An increase in absorbance of the reaction mixture indicated increased reduction of $\mathrm{Fe}^{+3}$.

Animals and experimental design. All the protocols used in this study were approved by the Ethical Committee of Directorate General for Scientific Research and Technological Development at Algerian Ministry of Higher Education and Scientific Research, permit no PNR/SF 08/2012. Twenty-four male albino Wistar rats weighing 250 \pm 13 g (aged 8-9 weeks) were provided by Pasteur Institute (Algiers, Algeria). They were housed in cages at room temperature of $23 \pm 2^{\circ} \mathrm{C}$ and kept under standard conditions of an average relative humidity of $40 \%$ and a natural photoperiod. The rats were fed a standard laboratory diet (standard food, supplied by the "ONAB of Bejaia", Algeria) and water was available ad libitum. The animals were habituated to these conditions for one month prior the experiments. The rats were randomly divided into four groups of six animals each:

Control: rats had free access to water and commercial standard pelleted food;

RDP (RDP-Treated group): received RDP in their drinking water $(269.9 \mathrm{mg} / \mathrm{kg} / \mathrm{B} . \mathrm{W})$;

$\mathrm{LuO}$ (LuO-Treated group): rats were force-fed with $\mathrm{LuO}$ (0.5 g/kg B.W.);

$\mathrm{RDP}+\mathrm{LuO}$ (RDP+LuO-Treated group): rats received both $\mathrm{RDP}$ and $\mathrm{LuO}$.

The dose of RDP used in this study represented 1/18 of $\mathrm{LD}_{50}(269.9 \mathrm{mg} / \mathrm{kg} \mathrm{B.W.).} \mathrm{This} \mathrm{dose} \mathrm{was} \mathrm{used} \mathrm{in} \mathrm{pre-}$ 
vious investigations as it is toxic, but not lethal to rats (El-Shenawy, 2009). The dose of $\mathrm{LuO}(0.5 \mathrm{~g} / \mathrm{kg} \mathrm{B.W.)}$ gave a good protection against Roundup toxicity (Hendawi et al., 2016). During the treatment period (30 days), food intake and water consumption, as well as body weight of the animals, were monitored regularly. At the end of the experiment, the animals fasted overnight and their total body weight was recorded. They were then sacrificed by cervical decapitation without anesthesia in order to minimize the animals' stress.

Biochemical analysis. Rats' blood was collected into non-heparinized tubes and centrifuged for $15 \mathrm{~min}$ at $3000 \mathrm{rpm}$ at $4^{\circ} \mathrm{C}$. Serum samples were stored at $-20^{\circ} \mathrm{C}$ for subsequent analysis of glucose, alanine aminotransferase (ALT), aspartate aminotransferase (AST), alkaline phosphatase (ALP), lactate dehydrogenase (LDH), gamma-glutamyl transferase (GGT), total bilirubin, total proteins, albumin, cholesterol, triglycerides, HDL, LDL, creatinine, urea and uric acid. All parameters were estimated using commercial kits from COBAS INTEGRA400 (glucose, ref. 2172682; AST, ref. 2056097; ALT, ref. 2056119; ALP, ref. 20766739 and 20759961; LDH, ref. 2055503; GGT, ref. 20759996; total bilirubin, Ref. 20737488; total proteins, ref. 2053039; albumin, ref. 20737461; Cholesterol, Ref. 20763012; Triglycerides, Ref. 2144620; HDL, Ref. 03038637; LDL, Ref. 03038866; creatinine, Ref. 20764345; urea, Ref. 2055660; uric acid, Ref. 2054728).

Tissue preparation. After the animals were sacrificed, their livers and kidneys were immediately removed, washed in a $0.9 \% \mathrm{NaCl}$ solution and weighed. The relative weight of these organs (\%) was calculated as $\mathrm{g} / 100 \mathrm{~g}$ body weight. Then, one lobe of liver and another of kidney were used for histological examination. The remaining lobes of liver and kidney were homogenized on ice in Tris-Buffered Saline $(1: 2 w / v ; 1 \mathrm{~g}$ of tissue with $2 \mathrm{ml}$ TBS: $50 \mathrm{mM}$ TRIS, $150 \mathrm{mM} \mathrm{NaCl}, \mathrm{pH}$ 7.4) and the cell suspension was centrifuged (9000 rpm, $15 \mathrm{~min}$ at $\left.4^{\circ} \mathrm{C}\right)$. The supernatants were divided into aliquots and then stored at $-20^{\circ} \mathrm{C}$ for oxidative parameters analysis.

Histopathological examination. Samples of tissues (livers and kidneys) were fixed in $10 \%$ formaldehyde. They were dehydrated in a series of increasing alcohol concentrations (70-100\%) (LEICA TP1020) and embedded in paraffin. The tissues were cut in $5 \mu \mathrm{m}$ thick slices using microtome (LEICA RM2235), then deparaffinized and stained with hematoxylin and eosin (H\&E) and examined using LEICA DM 1000LED microscope, following the method of Hould (Hould, 1984).

Measurement of lipid peroxidation levels. Malondialdehyde (MDA), which is the end product of oxidation of polyunsaturated fatty acids, was assessed as a marker for lipid peroxidation. MDA reacts with thiobarbituric acid (TBA) as TBARS to produce a red colored complex that has a peak absorbance at $532 \mathrm{~nm}$ (Buege \& Aust, 1978). The amount of TBRAS in a sample was calculated using an extinction coefficient of $1.56 \times 10^{5} \mathrm{M} / \mathrm{cm}$ and expressed in nmol MDA/mg of protein.

Measurement of advanced oxidation protein product contents. The advanced oxidation protein product (AOPP) is a marker of oxidant-mediated protein damage. Its level was determined according to the method of Kayali and others (Kayali et al., 2006) by the formation of dityrosine-containing and cross-linking protein products. The absorbance of the reaction mixture was immediately recorded at $340 \mathrm{~nm}$. The concentration of AOPP was expressed in $\mathrm{nmol} / \mathrm{mg}$ of protein.
Content of reduced glutathione. Reduced glutathione (GSH) content of liver and kidney homogenates was determined using a colorimetric technique described by Ellman (Ellman, 1959) and modified by Jollow and others (Jollow et al., 1974), which is based on measuring optical absorbance at $412 \mathrm{~nm}$ that reflects the reduction of DTNB [5,5'-dithiobis-(2-nitrobenzoic acid)] by -SH groups of glutathione. The total GSH content is expressed in nmol GSH/mg protein.

Content of vitamin C. Vitamin C (ascorbic acid) level measurement was performed as described by JacquesSilva and others (Jacques-Silva et al., 2001), using the oxidation of vitamin $C$ with copper to form dehydroascorbic acid. This product was further treated with 2,4dinitrophenylhydrazine to form an osazone, which, when treated with sulphuric acid, resulted in a colored product. Absorbance of the sample was measured at $540 \mathrm{~nm}$ and the result was expressed in mmol of ascorbic acid/mg of protein.

Measurement of antioxidant enzyme activities. The glutathione peroxidase (GPx) (E.C.1.11.1.9) activity in a sample was measured using the method of Flohé and Günzler (Flohé \& Günzler, 1984), based on the reduction of hydrogen peroxide $\left(\mathrm{H}_{2} \mathrm{O}_{2}\right)$ in the presence of reduced glutathione (GSH). The absorbance of the sample was recorded at $420 \mathrm{~nm}$. Specific GPx activity was expressed in mmol GSH/mg protein.

The glutathione-S-transferase (GST) (E.C.2.5.1.18) activity in the tissues was measured spectrophotometrically using the method of Habig et al., (1974). It is based on the conjugated reaction of glutathione and 1-chloro-2,4dinitrobenzene (CDNB) which, in turn, results in a new molecule that absorbs light at $340 \mathrm{~nm}$. The GST activity is expressed in $\mu \mathrm{mol} \mathrm{CDNB} / \mathrm{GSH} / \mathrm{min} / \mathrm{mg}$ protein.

The catalase (CAT) (E.C.1.11.1.6) activity was measured according to Aebi (Aebi, 1984). This assay is based on the ability of the enzyme to degrade hydrogen peroxide followed by the decrease in absorbance at $240 \mathrm{~nm}$ using a UV/visible light measured for $1 \mathrm{~min}$. CAT activity is expressed in $\mu \mathrm{mol} \mathrm{H}_{2} \mathrm{O}_{2}$ consumed $/ \mathrm{min} / \mathrm{mg}$ protein.

The superoxide dismutase (SOD) (E.C.1.15.11) activity in a sample was determined with the method of Beyer Jr and Fridovich (Beyer Jr \& Fridovich, 1987), using nitrotetrazolium blue tetrazolium (NBT) test and photo-reduction of riboflavin/methionine, which generates superoxide anion. In aerobic conditions, the mixture of riboflavin, methionine and NBT is blue. The presence of SOD inhibits the oxidation of NBT and changes the absorbance at $560 \mathrm{~nm}$. The changes in samples absorbance were recorded after 20 min of incubation of the reagents and tissue samples. Units of SOD activity were expressed as the amount of enzyme required to inhibit the reduction of NBT by $50 \%$. The activity was expressed as units/mg of protein.

Content of protein carbonyl groups. Protein carbonyl levels in the samples were estimated with the method described by Levine and others (Levine et al., 1990). The homogenates were incubated with 2,4-dinitrophenylhydrazine (DNPH) in 6M guanidine hydrochloride. As DNPH binds selectively to the protein carbonyl groups the absorbance at $370 \mathrm{~nm}$ changes. The level of protein carbonyls was expressed in $\mathrm{nmol} / \mathrm{mg}$ of protein.

Protein content estimation. The protein content of tissue samples was measured spectrophotometrically at $595 \mathrm{~nm}$ using the method of Bradford (Bradford, 1976), with bovine serum albumin as a standard.

Statistical analysis. All data were expressed as means \pm standard error means (S.E.M.) for six rats in each 
Table1. Amounts of total phenols content, total flavonoids, condensed tannins and anti-radicular DPPH scavenging activity in LuO

\begin{tabular}{lc}
\hline Studied parameters & Values \\
\hline $\begin{array}{l}\text { Total phenolic acids content }(\mathrm{mg} \mathrm{GAE} / 100 \mathrm{~g} \text { of } \\
\text { LuO) }\end{array}$ & $0.11 \pm 0.01$ \\
\hline Total flavonoid content $(\mathrm{mg} \mathrm{QE} / \mathrm{g} \mathrm{LuO}$ & $0.32 \pm 0.01$ \\
\hline Condensed tannins $(\mathrm{mg} \mathrm{CE} / \mathrm{g} \mathrm{LuO})$ & $0.25 \pm 0.02$ \\
\hline $50 \%$ scavenging concentration $(\mathrm{mg} / \mathrm{ml})$ on DPPH & $22.85 \pm 2.6$ \\
radical & $10.36 \pm 1.59$ \\
\hline FRAP test (EC50 mg/ml)
\end{tabular}

$\mathrm{n}=3, \mathrm{GAE}$, gallique acide equivalents; $\mathrm{QE}$, quercetin equivalents; $C E$, catechin equivalents.

group. The statistical analysis (comparison between all the groups) was performed with one-way ANOVA followed by Student's $t$-test to evaluate the significance of differences. $P<0.05$ was considered statistically significant.

\section{RESULTS}

\section{Antioxidant activity of LuO}

The total phenolic content of $\mathrm{LuO}$ product was 0.11 $\mathrm{mg}$ of CAE per $100 \mathrm{~g}$ of extract as shown in Table 1. The total flavonoid content is expressed as $0.32 \mathrm{mg}$ of quercetin equivalent per gram of $\mathrm{LuO}$. In addition, $\mathrm{LuO}$ contained $0.25 \mathrm{mg}$ of condensed tannins, expressed as $\mathrm{mg}$ of catechin equivalent per gram. The antioxidant activity (DPPH) $\mathrm{IC}_{50}$ was $22.85 \mathrm{mg} / \mathrm{ml}$, and ferric reducing antioxidant power (FRAP) was $\mathrm{IC}_{50}=10.36 \mu \mathrm{g} / \mathrm{ml}$, showing the reductive potential of $\mathrm{LuO}$.

\section{Effects of treatment on general rat health}

During the experimental period no deaths were observed in any group. The rats in the control and $\mathrm{LuO}$ groups showed no signs of systemic toxicity. However, the rats in RDP group showed clinical signs such as anorexia, loss of body weight, exhaustion, and inflammation of the salivary glands (the cause of drooling). All these clinical signs were related to the acute toxicity of RDP. Furthermore, the rats in $\mathrm{RDP}+\mathrm{LuO}$ group showed some symptoms of anorexia and loss of body weight.

\section{Effect of treatment on body, liver and kidney weight, food intake and water consumption}

As shown in Table 2, the final body weight and the absolute liver and kidney weight of rats decreased significantly in the RDP, $\mathrm{LuO}$ and $\mathrm{RDP}+\mathrm{LuO}$ groups of $(-38 \%,-13 \%$ and $-25 \%),(-21 \%,-14 \%$ and $-22 \%)$, $(-21 \%,-14 \%$ and $-22 \%)$ and $(-14 \%,-13 \%$ and $-13 \%$ ), respectively, compared to the control group. This decrease was associated with the reduction in food intake and water consumption in RDP, $\mathrm{LuO}$ and $\mathrm{RDP}+\mathrm{LuO}$ groups $(-19 \%,-14 \%$ and $-33 \%),(-24 \%$, $-9 \%$ and $-37 \%$, respectively), when compared to the control group. However, the administration of $\mathrm{LuO}$ correlated with a significant increase in absolute liver and kidney weight when compared to rats from the RDP group.

\section{Effect of treatment on serum biochemical parameters}

As shown in Table 3, administration of RDP caused hepatic toxicity in rats. Serum glucose levels in rats from the RDP group tended to be higher than in control. Furthermore, the enzymatic activity of AST, ALT, ALP, LDH, total bilirubin and GGT was significantly higher in rats exposed to RDP than in the control group (48\%, $37 \%$, and $43 \%, 58 \%, 29 \%$ and $115 \%$, respectively). In addition, urea and creatinine levels increased significantly in RDP group compared to the control group (11\% and $16 \%$ ), indicating nephrotoxicity. The levels of total protein and albumin in the serum were significantly lower in the RDP group. Similarly, the serum lipid profile in the RDP group showed a significant decrease in total cholesterol and triglycerides as compared to the control group $(8 \%$ and $21 \%$ ). However, the co-administration of $\mathrm{LuO}$ alleviated the RDP effect on blood biochemical variables.

\section{Antioxidant defense status in the liver and kidney}

Table 4 and Table 5 summarize the effects of RDP exposure and $\mathrm{LuO}$ administration on antioxidant defense systems in rat liver and kidneys. An increase in MDA (46\%, $17 \%$ respectively), AOPP $(18 \%, 14 \%$ respectively), and PCOs $(25 \%, 15 \%$ respectively) was observed in the RDP and LuO-RDP groups compared to the control. On the

Table 2. Effects of treatments on body weight $(\mathrm{g})$, absolute $(\mathrm{g})$ and relative liver and kidneys weights (g/100 $\mathrm{g}$ bw), daily food intake (g) and drinking water consumption $(\mathrm{ml})$ in experimental groups.

\begin{tabular}{|c|c|c|c|c|}
\hline Studied parameters & Control & RDP & LuO & $\mathrm{RDP}+\mathrm{LuO}$ \\
\hline Initial Body weights (g) & $249.6 \pm 2.7$ & $250.33 \pm 4.64$ & $250.5 \pm 7.29$ & $249.66 \pm 7.86$ \\
\hline Final Body weights (g) & $299.5 \pm 11.4$ & $\begin{array}{l}235.5 \pm 4^{* *} \\
p=0.0001\end{array}$ & $257.5 \pm 11.94$ & $\begin{array}{c}233.5 \pm 8.68 \\
p=0.33\end{array}$ \\
\hline Absolute liver weights (g) & $9.00 \pm 0.43$ & $\begin{array}{c}5.55 \pm 0.23^{* * * *} \\
p=0.001\end{array}$ & $7.79 \pm 0.21$ & $\begin{array}{c}6.70 \pm 0.49^{\# \#} \\
p=0.004\end{array}$ \\
\hline Absolute kidney weights (g) & $1.85 \pm 0.09$ & $\begin{array}{c}1.59 \pm 0.03^{* *} \\
p=0.013\end{array}$ & $1.61 \pm 0.07$ & $\begin{array}{c}1.59 \pm 0.05 \\
p=0.48\end{array}$ \\
\hline Food intake (g/day/rat) & $21.66 \pm 0.69$ & $\begin{array}{c}17.43 \pm 1.18^{* * * *} \\
p=0.0002\end{array}$ & $18.69 \pm 0.66$ & $\begin{array}{c}14.51 \pm 1.23 \# \# \\
p=0.0001\end{array}$ \\
\hline Quantities of drinking water consumption (ml/day/rat) & $32.65 \pm 2.34$ & $\begin{array}{c}24.84 \pm 2.85^{* * *} \\
p=0.00002\end{array}$ & $29.52 \pm 2.44$ & $\begin{array}{c}20.31 \pm 2.02 \text { \#\#\# } \\
p=0.0003\end{array}$ \\
\hline Quantities of RDP ingested (mg/day/rat) & - & $67.75 \pm 7.79$ & - & $\begin{array}{c}55.39 \pm 5.52^{\# \#} \\
p=0.002\end{array}$ \\
\hline
\end{tabular}

Values are given as mean \pm SEM for groups of 6 animals each. Significant difference: LuO, RDP groups compared to the control $\left(^{* *} p<0.01\right.$, *** $p<0.001)$, RDP+LuO compared to the RDP group (\#\# $p<0.01, \# \# p<0.001)$. 
Table 3. Effects of treatments on serum biochemical parameters

\begin{tabular}{|c|c|c|c|c|}
\hline Parameters studied & Control & $\mathrm{RDP}$ & LUO & $\mathrm{RDP}+\mathrm{LUO}$ \\
\hline Glucose & $0.99 \pm 0.01$ & $\begin{array}{c}1.09 \pm 0.03^{* *} \\
p=0.01\end{array}$ & $0.96 \pm 0.02$ & $\begin{array}{c}1.00 \pm 0.03^{\#} \\
p=0.04\end{array}$ \\
\hline ASAT & $221.06 \pm 24.12$ & $\begin{array}{c}330.42 \pm 20.06^{* *} \\
p=0.004\end{array}$ & $272.42 \pm 6.21$ & $\begin{array}{c}266.3 \pm 11.73^{\#} \\
p=0.05\end{array}$ \\
\hline ALAT & $66.5 \pm 1.75$ & $\begin{array}{c}91.5 \pm 7.20^{* *} \\
p=0.003\end{array}$ & $72.66 \pm 1.14$ & $\begin{array}{l}66.5 \pm 2 \# \# \\
0.003\end{array}$ \\
\hline $\mathrm{LDH}$ & $2188 \pm 223.16$ & $\begin{array}{c}3472.6 \pm 205.67^{* * * *} \\
p=0.0008\end{array}$ & $2406 \pm 124.01$ & $\begin{array}{c}2085.5 \pm 142.06^{\# \# \#} \\
p=0.001\end{array}$ \\
\hline $\mathrm{ALP}$ & $104.13 \pm 8.53$ & $\begin{array}{c}149.13 \pm 13.61^{* *} \\
p=0.009\end{array}$ & $106.4 \pm 3.02$ & $\begin{array}{c}114.51 \pm 3.18^{\# \#} \\
p=0.01\end{array}$ \\
\hline GGT & $8.01 \pm 0.55$ & $\begin{array}{l}17.3 \pm 1.38^{* * *} \\
p=0.00001\end{array}$ & $7.96 \pm 1.2$ & $\begin{array}{c}8.33 \pm 1.24 \# \# \# \\
p=0.0003\end{array}$ \\
\hline Bil.T & $1.03 \pm 0.07$ & $\begin{array}{c}1.33 \pm 0.13^{*} \\
p=0.04\end{array}$ & $0.66 \pm 0.05$ & $\begin{array}{c}0.43 \pm 0.04 \text { \#\#\# } \\
p=0.00002\end{array}$ \\
\hline Prot.T & $83.85 \pm 1.11$ & $\begin{array}{c}75.8 \pm 2.25^{* *} \\
p=0.004\end{array}$ & $85.56 \pm 1.93$ & $\begin{array}{c}83.86 \pm 1.51 \# \\
p=0.006\end{array}$ \\
\hline Alb & $33.42 \pm 2.27$ & $\begin{array}{c}26.98 \pm 1.62^{*} \\
p=0.02\end{array}$ & $35.85 \pm 1$ & $\begin{array}{c}33.58 \pm 2.04 \# \# \\
p=0.01\end{array}$ \\
\hline Cholesterol & $1.5 \pm 0.05$ & $\begin{array}{c}1.62 \pm 0.04^{*} \\
p=0.05\end{array}$ & $1.49 \pm 0.05$ & $\begin{array}{c}1.34 \pm 0.04 \text { \#\#\# } \\
p=0.0004\end{array}$ \\
\hline Triglycerides & $0.57 \pm 0.02$ & $\begin{array}{c}0.69 \pm 0.04^{*} \\
p=0.02\end{array}$ & $0.58 \pm 0.01$ & $\begin{array}{c}0.58 \pm 0.02^{\#} \\
p=0.02\end{array}$ \\
\hline $\mathrm{HDL}$ & $1.42 \pm 0.06$ & $\begin{array}{c}0.85 \pm 0.07^{* * * *} \\
p=0.0001\end{array}$ & $1.2 \pm 0.08$ & $\begin{array}{c}1.03 \pm 0.04 \# \\
p=0.04\end{array}$ \\
\hline LDL & $0.14 \pm 0.005$ & $\begin{array}{c}0.18 \pm 0.01^{* *} \\
p=0.01\end{array}$ & $0.10 \pm 0.009$ & $\begin{array}{c}0.16 \pm 0.02 \\
p=0.22\end{array}$ \\
\hline Urea & $12.35 \pm 0.47$ & $\begin{array}{c}13.72 \pm 0.45^{*} \\
p=0.03\end{array}$ & $11.64 \pm 0.23$ & $\begin{array}{c}12.45 \pm 0.55^{\#} \\
p=0.003\end{array}$ \\
\hline Creatinine & $34.66 \pm 0.71$ & $\begin{array}{c}40.5 \pm 1.38^{* * * *} \\
p=0.001\end{array}$ & $32.33 \pm 1.31$ & $\begin{array}{c}38.66 \pm 1.02^{\# \#} \\
p=0.15\end{array}$ \\
\hline
\end{tabular}

Values are given as mean \pm S.E.M. for groups of 6 animals each. Significant difference: LuO, RDP groups compared to the control $\left({ }^{*} p<0.05,{ }^{* *} p<0.01,{ }^{* * *} p<0.001\right)$, ${ }^{* R D P}+$ LuO compared to the RDP group $\left({ }^{*} p<0.05,{ }^{* \#} p<0.01,{ }^{* \# \#} p<0.001\right)$

Table 4. Antioxidant defense status in liver of treated and control rats.

\begin{tabular}{|c|c|c|c|c|}
\hline Studied parameters & Control & RDP & LuO & $\mathrm{RDP}+\mathrm{LuO}$ \\
\hline $\begin{array}{l}\text { MDA } \\
\text { (nmol/mg protein) }\end{array}$ & $23.41 \pm 3.13$ & $\begin{array}{c}34.33 \pm 1.71^{* *} \\
p=0.005\end{array}$ & $16.13 \pm 1.35$ & $\begin{array}{c}23.43 \pm 1.34 \# \# \# \\
0.0002\end{array}$ \\
\hline $\begin{array}{l}\text { AOPP } \\
\text { (nmol/mg protein) }\end{array}$ & $0.039 \pm 0.002$ & $\begin{array}{c}0.046 \pm 0.002^{* *} \\
p=0.01\end{array}$ & $0.038 \pm 0.001$ & $\begin{array}{c}0.04 \pm 0.002^{\#} \\
p=0.02\end{array}$ \\
\hline $\begin{array}{l}\text { PCO } \\
\text { (nmol/mg prot.) }\end{array}$ & $80.46 \pm 3.68$ & $\begin{array}{c}100.53 \pm 2.8^{* * *} \\
p=0.0007\end{array}$ & $81.16 \pm 2.25$ & $\begin{array}{c}82.83 \pm 4.75^{\# \#} \\
p=0.004\end{array}$ \\
\hline $\begin{array}{l}\mathrm{GSH} \\
(\mu \mathrm{mol} / \mathrm{mg} \text { prot. })\end{array}$ & $2.6 \pm 0.14$ & $\begin{array}{l}1.85 \pm 0.16^{* *} \\
p=0.003\end{array}$ & $2.39 \pm 0.12$ & $\begin{array}{c}3.11 \pm 0.14 \# \# \# \\
p=0.00003\end{array}$ \\
\hline $\begin{array}{l}\text { Vitamin C } \\
\text { (mmol ascorbic acid/mg of protein) }\end{array}$ & $1.0 \pm 0.01$ & $\begin{array}{c}0.94 \pm 0.02^{*} \\
p=0.03\end{array}$ & $1.0 \pm 0.01$ & $\begin{array}{c}1.0 \pm 0.006^{\#} \\
p=0.03\end{array}$ \\
\hline CAT ( $\mu \mathrm{mol} \mathrm{H} 2 \mathrm{O} 2 / \mathrm{min} / \mathrm{mg}$ protein) & $347.5 \pm 35.67$ & $\begin{array}{c}134.83 \pm 8.46^{* * *} \\
p=0.00002\end{array}$ & $328.83 \pm 23$ & $\begin{array}{c}347.66 \pm 21.41^{\# \#+} \\
p=0.00003\end{array}$ \\
\hline GPx (nmol GSH/min/mg protein) & $1.05 \pm 0.13$ & $\begin{array}{c}1.91 \pm 0.18^{* * *} \\
p=0.001\end{array}$ & $0.95 \pm 0.12$ & $\begin{array}{c}1.32 \pm 0.12^{\# \#} \\
p=0.01\end{array}$ \\
\hline $\begin{array}{l}\text { GST } \\
\text { (nmol/mg protein) }\end{array}$ & $0.13 \pm 0.02$ & $\begin{array}{c}0.05 \pm 0.002^{* * *} \\
p=0.001\end{array}$ & $0.1 \pm 0.007$ & $\begin{array}{c}0.08 \pm 0.01 \# \\
p=0.006\end{array}$ \\
\hline $\begin{array}{l}\text { SOD } \\
\text { (U/mg de protein) }\end{array}$ & $294.16 \pm 15.54$ & $\begin{array}{c}166.83 \pm 19.74^{* * * *} \\
p=0.0002\end{array}$ & $293.33 \pm 20.38$ & $\begin{array}{c}273.66 \pm 17.71 \# \#=0.001 \\
p=0\end{array}$ \\
\hline
\end{tabular}

Values are given as mean \pm S.E.M. for groups of 6 animals each. Significant difference: LuO, RDP groups compared to the control $\left({ }^{*} p<0.05,{ }^{* *} p<0.01,{ }^{* * *} p<0.001\right), "{ }^{*} \mathrm{RDP}+$ LuO compared to the RDP group $\left({ }^{*} p<0.05,{ }^{* \# p} p<0.01,{ }^{* \#} p<0.001\right)$. 
Table 5. Antioxidant defense status in kidney of treated and control rats.

\begin{tabular}{|c|c|c|c|c|}
\hline Studied parameters & Control & $\mathrm{RD} P$ & LuO & $\mathrm{RD} P+\mathrm{LuO}$ \\
\hline $\begin{array}{l}\text { MDA } \\
\text { (nmol/mg protein) }\end{array}$ & $28.07 \pm 1.18$ & $\begin{array}{c}32.92 \pm 1.31^{* *} \\
p=0.01\end{array}$ & $18.89 \pm 1.92^{* * *}$ & $\begin{array}{c}20.76 \pm 2.72^{\# \# \#} \\
p=0.001\end{array}$ \\
\hline $\begin{array}{l}\text { AOPP } \\
\text { (nmol/mg of protein) }\end{array}$ & $0.021 \pm 0.001$ & $\begin{array}{c}0.024 \pm 0.0007^{*} \\
p=0.05\end{array}$ & $0.023 \pm 0.002$ & $\begin{array}{c}0.02 \pm 0.002^{\#} \\
p=0.08\end{array}$ \\
\hline $\begin{array}{l}\text { PCO } \\
\text { (nmol/mg prot.) }\end{array}$ & $74.83 \pm 3.66$ & $\begin{array}{c}86.16 \pm 4.14^{*} \\
p=0.03\end{array}$ & $73.33 \pm 3.58$ & $\begin{array}{c}74.66 \pm 3.77^{\#} \\
p=0.03\end{array}$ \\
\hline $\begin{array}{l}\mathrm{GSH} \\
(\mu \mathrm{mol} / \mathrm{mg} \text { prot. })\end{array}$ & $0.75 \pm 0.03$ & $\begin{array}{c}0.63 \pm 0.03 * * \\
p=0.01\end{array}$ & $0.72 \pm 0.03$ & $\begin{array}{c}0.68 \pm 0.01 \\
p=0.14\end{array}$ \\
\hline Vitamin C & $0.43 \pm 0.010$ & $\begin{array}{c}0.029 \pm 0.014^{*} \\
p=0.05\end{array}$ & $0.038 \pm 0.015$ & $\begin{array}{c}0.035 \pm 0.018 \\
p=0.36\end{array}$ \\
\hline $\begin{array}{l}\text { CAT } \\
(\mu \mathrm{mol} \mathrm{H} 2 \mathrm{O} 2 / \mathrm{min} / \mathrm{mg} \text { protein) }\end{array}$ & $605 \pm 8.72$ & $\begin{array}{c}418.5 \pm 52.02^{* *} \\
p=0.002\end{array}$ & $571.83 \pm 68.04$ & $\begin{array}{c}471.01 \pm 35 \\
p=0.21\end{array}$ \\
\hline $\begin{array}{l}\text { GPx } \\
\text { (nmol of GSH/min/mg protein) }\end{array}$ & $0.57 \pm 0.07$ & $\begin{array}{l}0.76 \pm 0.06^{*} \\
\quad p=0.05\end{array}$ & $0.56 \pm 0.04$ & $\begin{array}{l}0.45 \pm 0.05^{\# \#} \\
p=0.002\end{array}$ \\
\hline $\begin{array}{l}\text { GST } \\
\text { (nmol/mg protein) }\end{array}$ & $0.06 \pm 0.004$ & $\begin{array}{c}0.051 \pm 0.002^{*} \\
p=0.05\end{array}$ & $0.066 \pm 0.006$ & $\begin{array}{c}0.054 \pm 0.006 \\
P=0.36\end{array}$ \\
\hline $\begin{array}{l}\text { SOD } \\
\text { (U/mg de protein) }\end{array}$ & $162.16 \pm 13.03$ & $\begin{array}{c}73.83 \pm 7.3^{* * *} \\
p=0.00002\end{array}$ & $197.83 \pm 21.45$ & $\begin{array}{c}134.5 \pm 7.31 \# \# \# \\
p=0.00004\end{array}$ \\
\hline
\end{tabular}

Values are given as mean \pm S.E.M. for groups of 6 animals each. Significant difference: LuO, RDP groups compared to the control $\left({ }^{*} p<0.05,{ }^{* *} p<0.01,{ }^{* * *} p<0.001\right), * \operatorname{RDP}+$ LuO compared to the RDP group $\left({ }^{*} p<0.05,{ }^{* \#} p<0.01^{\# \# *} p<0.001\right)$.
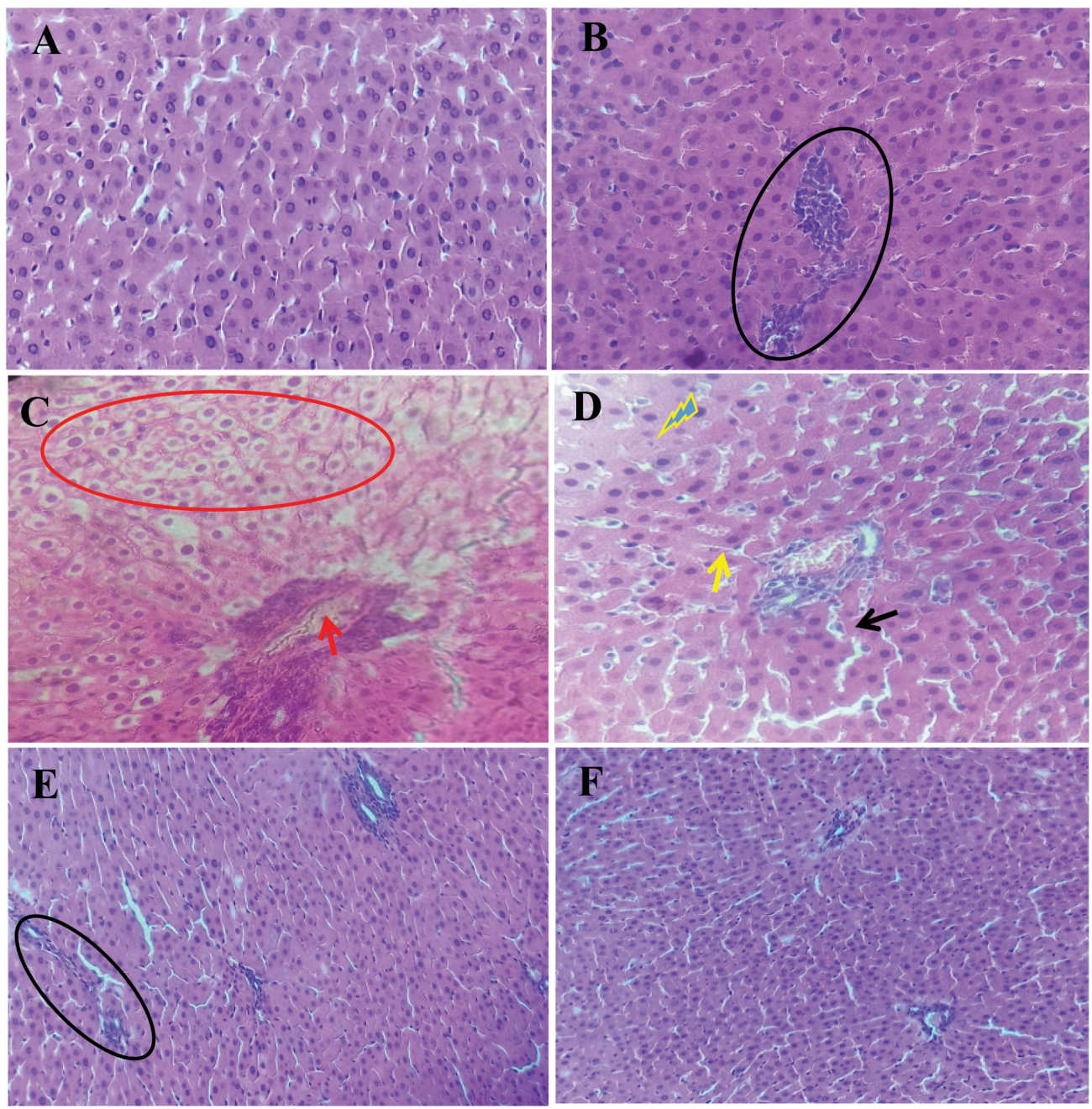

Figure 2. Effect of Roundup (RDP) and Linssed oil co-administrated with RDP on histopathological damages in the liver.

Controls $(A, x 40)$, treated with RDP (B to D, x40), LuO co-administrated with RDP $(E, x 40)$ and LuO $(F, x 40)$ after 4 weeks of treatment, as revealed by photomicrograph of H\&E. Vascular congestion (red arrow), mononuclear infiltration (black circle), dilation of sinusoids (black arrow), and hemorrhage (yellow arrow), necrosis ( $)$ and degeneration and ballooning of hepatocyte (red circle). 

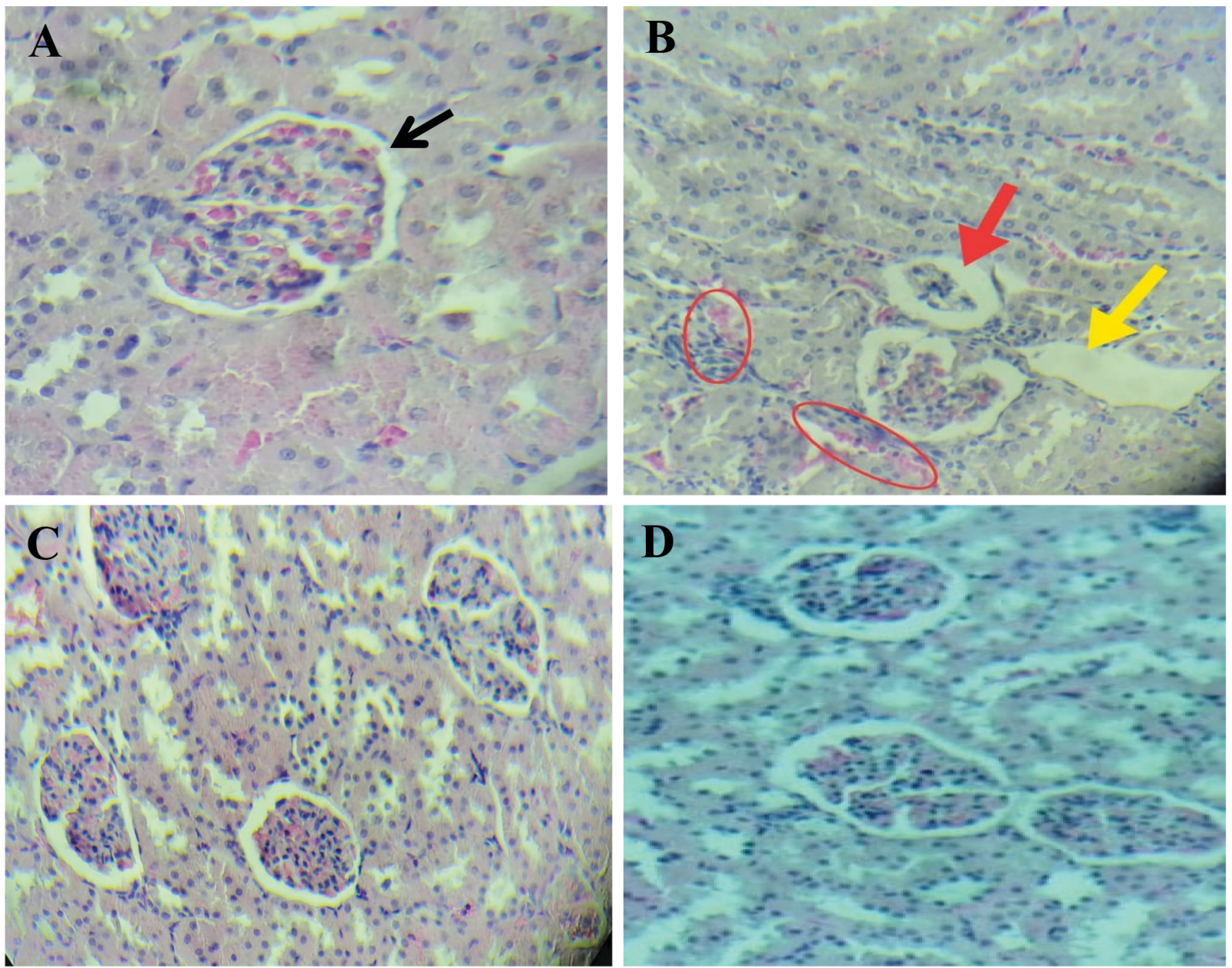

Figure 3. Effect of Roundup (RDP) and Linssed oil co-administrated with RDP on histopathological damages in the liver.

Controls ( $A, x 40)$, treated with RDP" $(B, x 40)$, LuO co-administrated with RDP $(C, x 40)$ and LuO $(D, x 40)$ after 4 weeks of treatment, as revealed by photomicrograph of H\&E. Space of Bowman (black arrow), tubular dilatation (yellow arrow), hemorrhagic (circle) and atrophied and collapsed malpighian (red arrow).

other hand, the activity of enzymatic and non-enzymatic antioxidants significantly decreased in the RDP and LuORDP groups as compared to the control: GSH (-28\%, $-15 \%$ respectively), Vit C (-6\%, $-14 \%$ respectively), CAT $(-61 \%,-30 \%$ respectively), GST $(-60 \%,-14 \%$ respectively) and SOD $(-43 \%,-54 \%$ respectively), and the level of GPx increased ( $80 \%, 31 \%$ respectively). In general, administration of LuO significantly improved the antioxidant parameters in the studied organs of rats treated with RDP.

\section{Histopathological Results}

Histopathological changes in rat liver and kidney resulting from RDP treatment are shown in Figs 2 and 3, Tables 6 and 7, respectively. The control rats presented normal hepatic morphology with distinct hepatocytes with prominent nuclei and no tissue damage (Fig. 2A). In contrast, liver sections of Roundup-treated rats showed severe structural damage characterized by mononuclear cell infiltration, periportal expansion, ballooning and degeneration of hepatocytes, necrosis, vascular congestion and sinusoidal dilatation (Fig. 2B to D). However, the livers of the rats from the $\mathrm{LuO}$ and RDP treated group had healthier histology than the rats from RDP-only treated group (Fig. 2E). No histological alteration in the liver was observed between the LuO and control groups (Fig. 2F). The histopathological kidney examination showed normal histology in the control group (Fig. 3A). However, the kidneys of rats exposed to Roundup exhibited glomerular dam-

Table 6. Semi quantitative scoring of histopathological changes in the liver sections of control and rats treated with Roundup (RDP), linseed oil (LuO) or their combination (RDP+LuO) after 4- week treatment.

\begin{tabular}{lcccc}
\hline Studied parameters & Control & RDP & LuO & RDP+LuO \\
\hline Mononuclear cell infiltration & - & +++ & - & + \\
\hline Hepatic hemorrhage & - & + & - & - \\
\hdashline Necrosis & - & ++ & - & - \\
\hline Vascular congestion & - & +++ & - & - \\
\hline Ballooning and degeneration of hepatocyte & - & +++ & - & - \\
\hline
\end{tabular}

$(-)$ indicates normal, $(+)$ indicates mild, $(++)$ indicates moderate, and (+++) indicates severe. 
Table 7. Semi quantitative scoring of histopathological changes in the kidney sections of control and rats treated with Roundup (RDP), linseed oil (LuO) or their combination (RDP+LuO) after 4- week treatment.

\begin{tabular}{lcc}
\hline Studied parameters & Control & RDP \\
\hline Atrophied Malpighian & - & ++ \\
\hline Tubular dilatation & - & +++ \\
\hline Hemorrhagic & - & ++ \\
\hline
\end{tabular}

$(-)$ indicates normal, (+) indicates mild, $(++)$ indicates moderate, and (+++) indicates severe.

age characterized by reduced Bowman space, atrophied and collapsed Malpighian glomeruli, tubulo-interstitial involvement of hemorrhagic suffusion zones, and dilation of proximal convoluted tubules (Fig. 3B). However, the co-administration of $\mathrm{LuO}$ with $\mathrm{RDP}$ resulted in a reduction in Bowman's space and normal cell morphology in the kidney when compared to Roundup-treated group (Fig. 3C). No histological alteration in the kidneys was observed between the $\mathrm{LuO}$ and control group of rats (Fig. 3D).

\section{DISCUSSION}

Exposure to toxic substances such as pesticides in the environment can contribute to the emergence of oxidative stress in biological systems and metabolic imbalance (Djeffal et al., 2015). Many studies have been conducted to relate Roundup ${ }^{\mathbb{B}}$ use to liver damage and renal failure in animals (Tang et al., 2017) and a number of human diseases (Seneff \& Orlando, 2018). Natural antioxidants have been considered to play an important role in counteracting the oxidative stress induced by various xenobiotics in tissues (Bouasla et al., 2014). In our experiments, the phytochemical analysis of flaxseed oil revealed the presence of phenolic acids compounds, flavonoids and condensed tannins, with a noticeable antioxidant activity. The antioxidant activity of $\mathrm{LuO}$ has been evaluated on the basis of radical scavenging effect on the free radical DPPH, which has been widely accepted as a tool for estimating the activities of antioxidants on free radicals (Beroual et al., 2017).

The obtained results demonstrated that exposure to Roundup ${ }^{\circledR}$ TURBO at $269.9 \mathrm{mg}$ RDP $/ \mathrm{kg} / \mathrm{day}$ b.w. in drinking water for 30 days caused a significant decrease in the rats' body weight and their liver and kidneys weight. These results were consistent with previous studies in adult rats exposed to various pyrethroid insecticides widely used in agriculture: imidacloprid, deltamethrin and methomyl (Kapoor et al., 2011; Saoudi et al., 2011; Djeffal et al., 2015). We supposed that the decrease in body weight observed in RDP-treated rats was probably due to the lower food intake, as RDP exposure may account for a reduced water and food intake. Our results are in agreement with those published by Tang and others (Tang et al., 2017) who have stated that the exposure to Roundup evokes a significant reduction in body weight, in liver and kidneys weight. Moreover, most physiological functions were modified in correlation with significant changes in food and water consumption. These observations were similar to those of the Çağlar and Kolankaya (Çağlar \& Kolankaya, 2008) and Barkat and others (Barkat et al., 2015). RDP and $\mathrm{LuO}$ treated rats also showed a significant reduction in body weight compared to control rats.

Flax is low in carbohydrates but extremely high in both soluble and insoluble fiber (Zhang et al., 2008). In traditional medicine, linseed oil is used in the diet be- cause taking flaxseed oil gives a feeling of fullness that lasts for a long time. As a result, the co-administration of $\mathrm{LuO}$ to RDP-treated group prevents the decrease in rats' absolute weight of liver and kidneys.

In the present study, a significant increase in blood glucose levels was recorded in Roundup-treated rats. This hyperglycemia may be due to an increase in insulin production and lesions in the islets of Langerhans and acinar cells caused by oxidative stress damage (Tizhe et al., 2018). Many authors report that the elevation of glucose rate in organophosphorus may indicate the disruption of carbohydrate metabolism emanating from the increased degradation of hepatic glycogen (Al-Attar, 2015). On the other hand, the RDP-treated rats exhibited a significant increase in TG, serum cholesterol, and LDL-C compared to the control rats. Hypertriglyceridemia and hypercholesterolemia can be explained by an increase in lipid rate peroxidation and free radicals release. MDA tested in the liver and kidneys in RDP-treated rats suggested a high lipid peroxidation. HDL-C could protect LDL-C against oxidation in vivo, since the lipids of HDL-C are preferentially oxidized before those of LDLC (Bowry et al., 1992). Our results agree well with those obtained by (Al-Attar, 2015; Meligi \& Hassan, 2017).

Flaxseed oil is rich in alpha-linolenic acid (ALA). It was shown that ALA supplementation improves glucose tolerance and reduces insulin resistance (Goncalves et al., 2018). The obtained results indicate that LuO administered orally attenuates the extensive changes in the energetic profile parameters such as glucose and lipid profile in RDP-treated rats (Costa et al., 2018; Pilar et al., 2017).

The liver is the first organ that protects the body from xenobiotics. Leak of liver enzymes such as ALT, AST, and ALP into the blood serum is a sign of hepatocellular damage and hepatic dysfunction (Bischoff et al., 2018). In our results, a significant increase in the activity of ALT, AST, ALP, LDH, and GGT occurred in the serum of RDP-treated rats as compared to the control ones. This elevation is probably due to a disruption of enzyme metabolism due to increased membrane permeability and leakage of these enzymes from hepatocytes into the blood (Dar et al., 2019). The present results were in line with the previous reports, which demonstrated that an increase in hepatic parameters was induced in rats exposed to Roundup and deltamethrin (Dar et al., 2019; Saoudi et al., 2011). Nevertheless, Cağlar and Kolankaya (Çağlar \& Kolankaya, 2008) observed a decrease in transaminase activity in rats that received glyphosatebased herbicide during 5 to 13 weeks. This discrepancy is probably due to the body adaptation during long exposure to the chemical. A significant increase in bilirubin blood levels was also observed in the Roundup -treated rats compared to the control group, confirming liver damage and its histopathological changes. Our data are in line with the observation that pesticides exposure exhibits clear-cut abnormalities in the biomarkers of tissue damage (Kanbur et al., 2015; Khan et al., 2013). In our study, long-lasting exposure to RDP caused a significant 
decrease in total protein and albumin levels in serum. These results are consistent with the findings of many other studies (Barkat et al., 2015; Uchendu et al., 2017), in which total protein and albumin levels in rats treated with organophosphorus pesticides were decreased. Irreversible changes induced by ROS, such as the formation of carbonylated proteins and the accumulation of these products in tissues, are usually associated with a permanent loss of protein function and are considered as indicators of oxidative damage and protein dysfunction (Fagan et al., 1999). It is interesting to note that the co-administration of RDP and LuO partially suppressed the hepatotoxic effect of RDP. The reduction in activity of the key hepatic enzymes indicates the regeneration process of hepatocyte membranes. An increase in blood bilirubin and normalization of both albumin and total proteins was also noticed. Similar results demonstrated that $\mathrm{LuO}$ attenuated severe changes in hepatic biochemical parameters in rats treated with pesticides (Chavan et al., 2013; Hana \& Sae, 2013; Hendawi et al., 2016). Another organ vulnerable to pesticide damage is the kidney, due to larger perfusion and increased concentration of excreted compounds that occur in renal tubular cells (Messarah et al., 2013). Serum levels of creatinine and urea were used as indicators of renal function. Elevated blood urea is known to be linked with an increased protein catabolism as a result of increased synthesis of arginase enzyme involved in urea production (Saoudi et al., 2011). In this study, increased serum creatinine and urea levels in rats treated with RDP reflected renal failure. Our results are similar to those obtained by Dedeke and others (Dedeke et al., 2018) who monitored changes in the kidney biomarkers in rats exposed to RDP. Uric acid is a final product of purine degradation and is eliminated in the urine. In our study, the increase in serum uric acid may be explained by a strong degradation of nucleic acids (DNA and RNA). Therefore, the high level of circulating uric acid may be an indicator of the effectiveness of cellular defense against the deleterious effects of free radicals. This may be the cause of the increase of uric acid in Roundup -treated rats (El-Shenawy, 2009). $\mathrm{LuO}$ administrated to rats was found to inhibit the RDP poisoning effects on the renal dysfunction markers (Hana \& Saed, 2013). Indeed, the imbalance between antioxidants and pro-oxidants causes damage to the integrity of the cell membrane (Slama et al., 2018). The impact of ROS on biological membranes is analyzed using a test determining the degree of lipid peroxidation and protein oxidation. The increase in ROS level in the cell may be due to either overproduction of these reactive substances, or a decrease in the cell's capacity to neutralize them (Kirschvink et al., 2008). Our research work demonstrated a significant increase in the level of MDA and AOPP in the liver and kidney in the RDP-treated group compared to the control group. The aromatic amino acids with a thiol group are the most sensitive to the oxidation and are a particular ROS target in proteins (Aydin et al., 2010). Moreover, our results showed an increase in PCO, whose elevation may be due to the formation of adducts between certain amino acid residues and lipid peroxidation products such as MDA (Stadtman \& Levine, 2006). These results are in correlation with previous reports (Abarikwu et al., 2015; Hamdaoui et al., 2016; Tang et al., 2017; Yazdinezhad et al., 2017), which suggested that organophosphate (glyphosate and chlorpyrifos) metabolism might generate reactive oxygen species (ROS), which in turn could lead to enhanced lipid peroxidation and protein oxidation. However, LuO supplementation causes a significant decrease in oxida- tive damage of protein and lipid peroxidation content in $\mathrm{RDP} / \mathrm{LuO}$ rats. Accordingly, in our study, the LuO protection against RDP could be based on the presence of the above-mentioned antioxidants. The linseed oil could transfer phenolic hydrogen to a peroxyl free radical of a peroxidized n-3 polyunsaturated fatty acid (PUFA) (Yang, 2012). Similar findings are reported by Karaca and Eraslan (Karaca \& Eraslan, 2013) and Pilar and others (Pilar et al., 2017). In fact, the body is able to produce endogenous antioxidants to reduce the damage caused by ROS, including GSH, Vit $\mathrm{C}$ and certain enzymes, such as SOD, CAT, GST and GPx (Khaldi et al., 2018). This thiol is abundant in living organisms in its reduced form (GSH). The reaction of glutathione with free radicals generates superoxide anion and glutathione in its oxidized form (GSSG). This could explain the fact that the cell attempts to maintain a low level of GSSG under physiological conditions and that some organs such as the liver and kidneys eliminate GSSG under oxidative stress (Cossu et al., 1997). Vit C plays a role of a protector of the cell compartment against free radicals (Djeffal et al., 2015). RDP-treated rats exhibited a significantly lower level of this antioxidant in the renal and hepatic tissues compared to the control rats. Our results revealed that the RDP administered in rats' drinking water caused a decrease in glutathione and vitamin $C$ levels in the liver and kidneys. This was due to the oxidation of GSH to GSSG to protect cells against oxidative damage (El-Shenawy, 2009; Hamdaoui et al., 2016; Kasmi et al., 2018).

The treatment with $\mathrm{LuO}$ was confirmed to increase the level of GSH and vit C. This result may be due to the protection mechanism of linseed oil against Roundup -induced toxicity by the reduction of GSSH and stabilized GSH level. The GPx and GST antioxidant enzymes found in the cytoplasm play a major role in the conversion of $\mathrm{H}_{2} \mathrm{O}_{2}$ and organic hydro-peroxides into water and alcohol using GSH as a cofactor (Slama et al., 2018). The significantly lower levels of GST in hepatic and kidney tissues in Roundup-treated rats may be a consequence of the decreased GSH level that is used to inhibit the enzymes and induce their inactivation in the case of excessive production of $\mathrm{H}_{2} \mathrm{O}_{2}$ due to lipid peroxidation (Bhondave et al., 2014). In fact, the results of our experiment also showed a highly significant increase in GPx of rats after exposure to RDP. However, (Djeffal et al., 2015) have described an increase in GPx activity, suggesting that elevated enzymatic activity counteracts the oxidative stress induced by methomyl, and affirming that it is a way of adaptation of the body. The activities of GPx and GST enzymes are in concordance with the study of (Abarikwu et al., 2015). CAT and SOD antioxidant enzymes are the first line of defense against the detrimental effects of free radical damage. They also convert superoxide radicals into $\mathrm{H}_{2} \mathrm{O}_{2}$. This function is only effective if it is followed by the actions of CAT, since the $\mathrm{H}_{2} \mathrm{O}_{2}$ produced by SOD is subsequently cleaned by the CAT (Zemmouri et al., 2017). This explains why in this study we found a decrease in enzymatic activity of SOD and CAT in the treated rats compared to the control group, in all the studied tissue compartments (Abdel-Daim et al., 2019; Turkmen et al., 2019). Rats co-treated with LuO showed a significant improvement of the antioxidant enzymes GPx, GST, CAT and SOD activity when compared to RDP-treated rats. These findings constitute further evidence of $\mathrm{LuO}$ powerful antioxidant potential (Hendawi et al., 2016; Pilar et al., 2017; Xu et al., 2017; Wei Yang et al., 2012). 
Histopathological studies corroborated the biochemical analysis. In particular, Roundup -exposed rats showed the infiltration of inflammatory cells, presence of degenerating and ballooning hepatocytes, necrosis, glomerular damage, and dilation of proximal convoluted tubules impairment in rats' hepatic and kidney cells. These results are in agreement with those obtained in other studies (Abarikwu et al., 2015; Al-Attar 2015; Hamdaoui et al., 2016; Larsen et al., 2012; Tang et al., 2017; Turkmen et al., 2019), showing that Roundup evoked histopathological changes in liver and kidney tissue in rats. The protective activity of $\mathrm{LuO}$ has been demonstrated in rats with RDP-induced hepatic and renal toxicity. This is due to its high levels of omega-3 and ALA, which can protect against the oxidative damage of liver and kidney cell membranes via the free radical scavenging (Yang et al., 2012). Furthermore, a protective effect of linseed has been reported against thiacloprid, cadmium, astaxanthin and hepatic steatosis (Goncalves et al., 2018; Hendawi et al., 2016; Karaca \& Eraslan, 2013; Xu et al., 2017).

\section{CONCLUSION}

In conclusion, the present study showed that Roundup was able to induce oxidative damage in adult rats by increasing lipid peroxidation, protein carbonylation, and protein oxidation associated with decreased antioxidant enzymatic activity, reduced glutathione content in the liver and kidneys. Given the biochemical effects of RDP in serum, there is a risk of cytotoxicity in farmers and other people who may be in contact with RDP-containing pesticides. Furthermore, the aggravation of inflammation and oxidative stress was confirmed with histological changes observed in our study. The use of linseed oil as an antioxidant proved effective in reducing oxidative stress in liver and kidney and preserved the integrity of tissue structure.

\section{Acknowledgments}

The authors also wish to extend their thanks to Mrs. Leila MAHFOUDHI, Emeritus Teacher of English at the Sfax Faculty of Sciences, for having proofread and polished the language of the manuscript.

\section{Interest conflict}

The authors reported no potential conflict of interest.

\section{REFERENCES}

Abarikwu SO, Akiri OF, Durojaiye, MA, Adenike A (2015) Combined effects of repeated administration of Bretmont Wipeout (glyphosate) and Ultrazin (atrazine) on testosterone, oxidative stress and sperm quality of Wistar rats. Toxicol Mech Methods 25: 70-80. https://doi.or g/10.3109/15376516.2014.989349

Abdel-Daim MM, Dessouki AA, Abdel-Rahman, HG, Eltaysh R, Alkahtani S (2019) Hepatorenal protective effects of taurine and Nacetylcysteine against fipronil-induced injuries: The antioxidant status and apoptotic markers expression in rats. Sci Total Environ 650: 2063-2073. https://doi.org/10.1016/j.scitotenv.2018.09.313

Aebi H (1984) Catalase in vitro. Methods in ensymology 105: 121-126. https://doi.org/10.1016/S0076-6879(84)05016-3

Al-Attar AM (2015) Effect of grapeseed oil on diazinon-induced physiological and histopathological alterations in rats. Saudi J Biol Sci 22: 284-292. https://doi.org/10.1016/i.sjbs.2014.12.010

Almeida LL, Teixeira AAC, Soares AF, Cunha FMD, Silva VADJ, Vieira Filho LD, Wanderley-Teixeira V (2017) Effects of melatonin in rats in the initial third stage of pregnancy exposed to sublethal doses of herbicides. Acta Histochem 119: 220-227. https://doi. org/10.1016/j.acthis.2017.01.003
Aydin S, Atukeren P, Cakatay U, Uzun H, Altug T (2010) Genderdependent oxidative variations in liver of aged rats. Biogerontology 11: 335-346. https://doi.org/10.1007/s10522-009-9257-8

Barkat L, Boumendjel A, Abdennour C, Boulakoud MS, El Feki A, Messarah M (2015) Methidathion-induced hematological, biochemi$\mathrm{cal}$ and hepatohistological alterations in rat: Ameliorative effects of selenium and zinc. African J Biotechnol 14: 1796-1806. https://dx.doi. org/10.5897/AJB2015.14466

Battaglin WA, Meyer MT, Kuivila KM, Dietze JE (2014) Glyphosate and its degradation product ampa occur frequently and widely in u.s. soils, surface water, groundwater, and precipitation. $J A W \mathrm{R} A$ Journal of the American Water Resources Association 50: 275-290. https://doi.org/10.1111/jawr.12159

Beroual K, Agabou A, Abdeldjelil MC, Boutaghane N, Haouam S, Hamdi-Pacha Y (2017) Evaluation of crude flaxseed (Linum usitatissimum L.) oil in burn wound healing in New Zealand rabbits. African J Trad Comp Altern Med 14: 280-286. https://doi.org/10.21010/ ajtcam.v14i3.29

Beyer Jr, WF, Fridovich I (1987) Assaying for superoxide dismutase activity: some large consequences of minor changes in conditions. Anal Biochem 161: 559-566. https://doi.org/10.1016/00032697(87)90489-1

Bhondave PD, Devarshi PP, Mahadik KR, Harsulkar AM (2014) Ashvagandharishta'prepared using yeast consortium from Woodfordia fruticosa flowers exhibit hepatoprotective effect on $\mathrm{CCl} 4$ induced liver damage in Wistar rats. J Ethnopharmacol 151: 183-190. https:// doi.org/10.1016/j.jep.2013.10.025

Bischoff K, Mukai M, Ramaiah SK (2018) Liver Toxicity. 239-257. https://doi.org/10.1016/b978-0-12-811410-0.00015-5

Blois MS (1958) Antioxidant determinations by the use of a stable free radical. Nature 181: 1199. https://doi.org/10.1038/1811199a0

Bouasla I, Bouasla A, Boumendjel A, Messarah M, Abdennour C, Boulakoud MS, El Feki A (2014) Nigella sativa oil reduces aluminium chloride-induced oxidative injury in liver and erythrocytes of rats. Biol Trace Elem Res 162: 252-261. https://doi.org/10.1007/s12011014-0114-5

Bowry VW, Stanley KK, Stocker R (1992). High density lipoprotein is the major carrier of lipid hydroperoxides in human blood plasma from fasting donors. Proce Natl Acad Sci 89: 10316-10320. https:// doi.org/10.1073/pnas.89.21.10316

Bradford MM (1976) A rapid and sensitive method for the quantitation of microgram quantities of protein utilizing the principle of proteindye binding. Anal Biochem 72: 248-254. https://doi.org/10.1006/ abio. 1999.4298

Buege JA, Aust SD (1978) Microsomal lipid peroxidation. Methods Enzymol 52: 302-310. https://doi.org/10.1016/S0076-6879(78)52032-6

Çağlar S, Kolankaya D (2008) The effect of sub-acute and sub-chronic exposure of rats to the glyphosate-based herbicide Roundup. Environ Toxicol Pharmacol 25: 57-62. https://doi.org/10.1016/j. etap.2007.08.011

Chavan T, Khadke SP, Harke SM, Ghadge AA, Karandikar M, Pandit, VA, Ranjekar PK, Kulkarni OS, Kuvalekar A (2013) Hepatoprotective effect of polyunsaturated fatty acids against repeated subacute acetaminophen dosing in rats. Int J Pharm Bio Sci 4: 286-295

European Food Safety Authority (EFSA) (2015) Conclusion on the peer review of the pesticide risk assessment of the active substance glyphosate. EFS A J 13. https://doi.org/10.2903/j.efsa.2015.4302

Cossu C, Doyotte A, Jacquin M, Babut M, Exinger A, Vasseur P (1997) Glutathione reductase, selenium-dependent glutathione peroxidase, glutathione levels, and lipid peroxidation in freshwater bivalves, Unio tumidus, as biomarkers of aquatic contamination in field studies. Ecotoxicol Environ Saf 38: 122-131. https://doi.org/10.1006/ eesa.1997.1582

DA Costa CAS, DA Camara Boueri BF, Pessanha CR, Boaventura GT (2018) Effects of flour or flaxseed oil upon testis mass in rats subjected to early weaning. Nat Prod Res 32: 987-990. https://doi.org/1 $0.1080 / 14786419.2017 .1374262$

Dai P, Hu P, Tang J, Li Y, Li C (2016) Effect of glyphosate on reproductive organs in male rat. Acta Histochem 118: 519-526. https://doi. org/10.1016/j.acthis.2016.05.009

Dar MA, Sultana M, Mir AH, Raina R, Prawez S (2019) Effect of repeated oral administration of Roundup ${ }^{\circledR}$ and ammonium nitrate on liver of wistar rats. Proc Natl Acad Sci, India Section B: Biol Sci 89: 505-510. https://doi.org/10.1007/s40011-017-0961-x

Dedeke GA, Owagboriaye FO, Ademolu KO, Olujimi OO, Aladesida AA (2018) Comparative assessment on mechanism underlying renal toxicity of commercial formulation of roundup herbicide and glyphosate alone in male albino rat. Int J Toxicol 37: 285-295. https://doi.org/10.1177/1091581818779553

Djeffal A, Messarah M, Boumendjel A, Kadeche L, Feki AE (2015) Protective effects of vitamin $C$ and selenium supplementation on methomyl-induced tissue oxidative stress in adult rats. Toxicol Ind Health 31: 31-43. https://doi.org/10.1177/0748233712468020

El-Shenawy NS (2009) Oxidative stress responses of rats exposed to Roundup and its active ingredient glyphosate. Environ Toxicol Pharmacol 28: 379-385. https://doi.org/10.1016/j.etap.2009.06.001 
Ellman GL (1959) Tissue sulfhydryl groups. Arch Biochemi Biophys 82: 70-77. https://doi.org/10.1016/0003-9861(59)90090-6

Fagan JM, Sleczka BG, Sohar I (1999) Quantitation of oxidative damage to tissue proteins. Int J Biochem Cell Biol 31: 751-757. https:// doi.org/10.1016/S1357-2725(99)00034-5

Flohé L, Günzler WA (1984) Assays of glutathione peroxidase. Methods Enzymol 105: 114-120. https://doi.org/10.1016/S0076-6879(84)0501

Goncalves NB, Bannitz RF, Silva BR, Becari DD, Poloni C, Gomes PM, Foss MC, Foss-Freitas MC (2018) Alpha-Linolenic acid prevents hepatic steatosis and improves glucose tolerance in mice fed a high-fat diet. Clinics (Sao Paulo) 73: e150. https://doi.org/10.6061/ clinics/2018/e150

Habig WH, Pabst MJ, Jakoby WB (1974). Glutathione S-transferases the first enzymatic step in mercapturic acid formation. I Biol Chem 249: 7130-7139

Hamdaoui L, Naifar M, Mzid M, Ben Salem M, Chtourou A, Ayedi F, Sahnoun Z, Rebai T (2016). Nephrotoxicity of Kalach 360 SL: biochemical and histopathological findings. Toxicol Mechanisms Methods 26: 685-691. https://doi.org/10.1080/15376516.2016.1230918

Hana RS, Saed N (2013) Alteration in oxidants, antioxidants and cytokines levels in blood of malathion exposed human and animal groups and the effect of flaxseed oil in alleviating malathion toxic effects. Eur J Biotechnol Biosci 1: 8-19

Hendawi YH, Alam RTM, Abdellatief SA (2016) Ameliorative effect of flaxseed oil against thiacloprid-induced toxicity in rats: hematological, biochemical, and histopathological study. Environ Sci Pollut Res Int 23: 11855-11863. https://doi.org/10.1007/s11356-016-6376-'

Heritier L, Duval D, Galinier R, Meistertzheim AL, Verneau O (2017). Oxidative stress induced by glyphosate-based herbicide on freshwater turtles. Environ Toxicol Chem 36: 3343-3350. https://doi. org/10.1002/etc.3916

Hould R (1984) Methode de Fontana: Techniques d'histopathologie et de cytopathologie.

Jacques-Silva MC, Nogueira CW, Broch L C, Flores ÉM, Rocha JBT (2001) Diphenyl diselenide and ascorbic acid changes deposition of selenium and ascorbic acid in liver and brain of mice. Pharmacol Tox icol 88: 119-125. https://doi.org/10.1034/j.1600-0773.2001.d01-92.x

Jamilian M, Hashemi Dizaji S, Bahmani F, Taghizadeh M, Memarzadeh MR, Karamali M, Akbari M, Asemi Z (2017). A Randomized controlled clinical trial investigating the effects of omega- 3 fatty acids and vitamin e co-supplementation on biomarkers of oxidative stress inflammation and pregnancy outcomes in gestational diabetes. Can Diabetes 41: 143-149. https://doi.org/10.1016/j.jcjd.2016.09.004

Jollow D, Mitchell J, Zampaglione Na, Gillette J (1974) Bromobenzene-induced liver necrosis. Protective role of glutathione and evidence for 3, 4-bromobenzene oxide as the hepatotoxic metabolite. Pharmacology 11: 151-169. https://doi.org/10.1159/000136485+

Julkunen-Tiitto R (1985) Phenolic constituents in the leaves of northern willows: methods for the analysis of certain phenolics. I Agricult Food Chem 33: 213-217. https://doi.org/10.1021/jf00062a012

Kanbur M, Eraslan G, Ince S, Altintas L, Liman BC, Bayram L (2015) The effects of propetamphos, cypermethrin and propetamphos-cypermethrin combination on some biochemical and histopathological parameters in mice. J KafKas Univ Vet Fakultesi Dergisi 21: 187-194. https://doi.org/10.9775/kvfd.2014.12004

Kapoor U, Srivastava MK, Srivastava LP (2011) Toxicological impact of technical imidacloprid on ovarian morphology, hormones and antioxidant enzymes in female rats. Food Chem Toxicol 49: 30863089. https://doi.org/10.1016/i.fct.2011.09.009

Karaca S, Eraslan G (2013) The effects of flaxseed oil on cadmiuminduced oxidative stress in rats. Biol Trace Elem Res 155: 423-430. https://doi.org/10.1007/s12011-013-9804-7

Kasmi S, Bkhairia I, Harrabi B, Mnif H, Marrakchi R, Ghozzi H, Kallel C, Nasri M, Zeghal K, Jamoussi k, Hakim, A. (2018 Modulatory effects of quercetin on liver histopathological, biochemical, hematological, oxidative stress and DNA alterations in rats exposed to graded doses of score 250. Toxicol Mech Methods 28: 12-22. https:// doi.org/10.1080/15376516.2017.1351507

Kayali R, Çakatay U, Akçay T, Altuğ T (2006) Effect of alpha-lipoic acid supplementation on markers of protein oxidation in post-mitotic tissues of ageing rat. Cell Biochem Funct 24: 79-85. https://doi. org/10.1002/cbf.1190

Khaldi T, Chekchaki N, Boumendjel M, Taibi F, Abdellaoui M, Messarah M, Boumendjel A (2018) Ameliorating effects of Nigella sative oil on aggravation of inflammation, oxidative stress and cytotoxicity induced by smokeless tobacco extract in an allergic asthma model in Wistar rats. Allergol Immunopathol (Madr) 46: 472-481. https://doi. org/10.1016/j.aller.2018.02.005

Khan HAA, Akram W, Shad SA, Lee JJ (2013). Insecticide mixtures could enhance the toxicity of insecticides in a resistant dairy population of Musca domestica L. PloS One 8: e60929. https://doi. org/10.1371/journal.pone.0060929

Kirschvink N, de Moffarts B, Lekeux P (2008). The oxidant/antioxidant equilibrium in horses. Vet J 177: 178-191. https://doi. org/10.1016/j.tvj1.2007.07.033
Knudsen LE, Hansen PW, MizrakV S, Hansen HK, Morck TA, Nielsen F, Siersma V Mathiesen L (2017). Biomonitoring of Danish school children and mothers including biomarkers of PBDE and Glyphosate. Rev Environ Health 32: 279-290

Larsen K, Najle R, Lifschitz A, Virkel G (2012) Effects of sub-lethal exposure of rats to the herbicide glyphosate in drinking water: glutathione transferase enzyme activities, levels of reduced glutathione and lipid peroxidation in liver, kidneys and small intestine. Environ Toxicol Pharmacol 34: 811-818. https://doi.org/10.1016/j. etap.2012.09.005

Levine RL, Garland D, Oliver CN, Amici A, Climent, I, Lenz, AG Ahn BW, Shaltiel S, Stadtman ER (1990) Determination of carbonyl content in oxidatively modified proteins. Methods Enzymol 186: 464 478. https://doi.org/10.1016/0076-6879(90)86141-h

Meligi NM, Hassan HF (2017) Protective effects of Eruca sativa (rocket) on abamectin insecticide toxicity in male albino rats. Environ Sci Pollut Res Int 24: 9702-9712. https://doi.org/10.1007/s11356-0178671-8

Messarah M, Saoudi M, Boumendjel A, Kadeche L, Boulakoud M S, El Feki A (2013) Green tea extract alleviates arsenic-induced biochemical toxicity and lipid peroxidation in rats. Toxicol Ind Health 29: 349-359. https:/ doi:10.1177/0748233711433934

Mohammadirad A, Abdollahi M (2011) A systematic review on oxidant/antioxidant imbalance in aluminium toxicity. Int J Pharmacol 7: 12-21. https://doi.org/10.3923/ijp.2011.12.21

Pan Y, Wang K, Huang S, Wang H, Mu X, He C, Ji X, Zhang J, Huang F (2008) Antioxidant activity of microwave-assisted extract of longan (Dimocarpus Longan Lour.) peel. Food Chemistry 106: 1264 1270

Pilar B, Gullich A, Oliveira P, Stroher, D, Piccoli J, Manfredini V (2017) Protective role of flaxseed oil and flaxseed lignan secoisolariciresinol diglucoside against oxidative stress in rats with metabolic syndrome. J Food Sci 82: 3029-3036. https://doi.org/10.1111/17503841.13964

Pourmorad F, Hosseinimehr S, Shahabimajd N (2006) Antioxidant activity, phenol and flavonoid contents of some selected Iranian medicinal plants. African J Biotechnol 5. ??? pages, doi

Rebai O, Belkhir M, Boujelben A, Fattouch S, Amri M (2017) Morus alba leaf extract mediates neuroprotection against glyphosate -induced toxicity and biochemical alterations in the brain. Environ Sci Pollut Res Int 24: 9605-9613. https://doi.org/10.1007/s11356-0178584-6

Rubilar M, Gutiérrez C, Verdugo M, Shene C, Sineiro J (2010) Flaxseed as a source of functional ingredients. J Soil Sci Plant Nutrit 10: 373-377. http://dx.doi.org/10.4067/S0718-95162010000100010

Saoudi M, Messarah M, Boumendjel A, Jamoussic K, El Feki AF (2011) Protective effects of vitamin C against haematological and biochemical toxicity induced by deltamethrin in male Wistar rats. Ecotoxicol Environ Saf 74: 1765-1769. https://doi.org/10.1016/j. ecoenv.2011.04.003

Seneff S, Orlando L (2018) Is glyphosate a key factor in mesoamerican nephropathy. J Environ Anal Toxicol 7: 2161-0525.1000542. http:// dx.doi.org/10.4172/2161-0525.1000542

Slama K, Boumendjel M, Taibi F, Boumendjel A, Messarah M (2018) Atriplex halimus aqueous extract abrogates carbon tetrachlorideinduced hepatotoxicity by modulating biochemical and histological changes in rats. Arch Physiol Biochem 1-12. https://doi.org/10.1080/ 13813455.2018.1489852

Stadtman ER, Levine RL (2006) Chemical modification of proteins by reactive oxygen species. Redox proteomics: from protein modifications to cellular dysfunction and diseases 9: 293-304

Tang J, Hu P, Li Y, Win-Shwe TT, Li C (2017) Ion imbalance is involved in the mechanisms of liver oxidative damage in rats exposed to glyphosate. Front Physiol 8: 1083. https://doi.org/10.3389/ fphys.2017.01083

Tizhe E, Ibrahim N, Fatihu M, Ambali S, Igbokwe I, Tizhe U (2018) Pancreatic function and histoarchitecture in Wistar rats following chronic exposure to Bushfire $(\mathrm{R})$ : the mitigating role of zinc. I Int Med Res 46: 3296-3305. https://doi.org/10.1177/0300060518778640

Tizhe EV, Ibrahim ND, Fatihu MY, Onyebuchi II, George BD, Ambali SF, Shallangwa JM (2014) Influence of zinc supplementation on histopathological changes in the stomach, liver, kidney, brain, pancreas and spleen during subchronic exposure of Wistar rats to glyphosate. Comp Clin Path 23: 1535-1543. https://doi.org/10.1007/ S00580-013-1818-1

Turkmen R, Birdane YO, Demirel HH, Yavuz H, Kabu M, Ince S (2019) Antioxidant and cytoprotective effects of N-acetylcysteine against subchronic oral glyphosate -based herbicide-induced oxidative stress in rats. Environ Sci Pollut Res Int 26: 11427-11437. https://doi.org/10.1007/s11356-019-04585-5

Uchendu C, Ambali SF, Ayo JO, Esievo KA (2017) The protective role of alpha-lipoic acid on long-term exposure of rats to the combination of chlorpyrifos and deltamethrin pesticides. Toxicol Ind Health 33: 159-170. https://doi.org/10.1177/0748233715616553

Varghese MV, Abhilash M, Alex M, Paul MVS, Prathapan A, Raghu KG, Nair RH (2017). Attenuation of arsenic trioxide induced car- 
diotoxicity through flaxseed oil in experimental rats. Redox Report 22: 346-352. https://doi.org/10.1080/13510002.2017.1289313

Wolfe K, Wu X, Liu RH (2003). Antioxidant activity of apple peels. I Agric Food Chem 51: 609-614. https://doi.org/10.1021/jf020782a

Xu J, Rong S, Gao H, Chen C, Yang W, Deng Q, Huang Q, Xiao L, Huang F (2017) A combination of flaxseed oil and astaxanthin improves hepatic lipid accumulation and reduces oxidative stress in high fat-diet fed rats. Nutrients 9. https://doi.org/10.3390/ nu9030271

Yang W, Fu J, Yu M, Huang Q, Wang D, Xu J, Deng Q, Yao P, Huang F, Liu L (2012) Effects of flaxseed oil on anti-oxidative system and membrane deformation of human peripheral blood erythrocytes in high glucose level. Lipids Health Disease 11: 88. https:// doi.org/10.1186/1476-511X-11-88

Yazdinezhad A, Abbasian M, Hojjat Hosseini S, Naserzadeh P, AghAtabay AH, Hosseini MJ (2017) Protective effects of Ziziphora ten- uior extract against chlorpyrifos induced liver and lung toxicity in rat: Mechanistic approaches in subchronic study. Environ Toxicol 32: 2191-2202. https://doi.org/10.1002/tox.22432

Ye Z, Li R, Cao C, Xu YJ, Cao P, Li Q, Liu Y (2019) Fatty acid profiles of typical dietary lipids after gastrointestinal digestion and absorbtion: A combination study between in-vitro and in-vivo. Food Chem 280: 34-44. https://doi.org/10.1016/j.foodchem.2018.12.032

Zemmouri H, Sekiou O, Ammar S, El Feki A, Bouaziz M, Messarah M, Boumendjel A (2017) Urtica dioica attenuates ovalbumin-induced inflammation and lipid peroxidation of lung tissues in rat asthma model. Pharm Biol 55: 1561-1568. https://doi.org/10.1080/138802 09.2017.1310905

Zhang ZS, Wang LJ, Li D, Jiao SS, Chen XD, Mao ZH (2008) Ultrasound-assisted extraction of oil from flaxseed. Separation Purif Technol 62: 192-198. https://doi.org/10.1016/j.seppur.2008.014 